TEME, г. XLIV, бр. 2, април - јун 2020, стр. 461-474

Прегледни рад $\quad$ https://doi.org/10.22190/TEME180709002A

Примљено: 9. 7. 2018.

UDK 658.7

Ревидирана верзија: 14. 1. 2019.

Одобрено за штампу: 15. 4. 2020.

\title{
UPSTREAM SUPPLY CHAIN DILEMMA - SINGLE OR MULTIPLE SOURCING
}

\author{
Aleksandra Andjelković ${ }^{*}$, Goran Milovanović \\ University of Niš, Faculty of Economics, Niš, Serbia \\ *aleksandra_caka@yahoo.com
}

\begin{abstract}
Supply chains, as networks of companies, are focused on creating greater value to meet market needs with aim to achieve higher profitability. In this regard, all activities and processes within supply chain, starting from supply of raw materials until to the delivery of final products at the market, must be organized bearing in mind the aim of the supply chain. The focus of the paper is on upstream supply chian, and on solving the dilemma of supplying from single or muliple sources. The significance of this part of supply chain arises from the fact that any potential disorder or disruption in supplying can jeopardize making the value for consumers and the survival of the whole chain. Considering that due to the reduction in the complexity of upstream supply chain management, there is a trend of supplier base reduction, the aim of the paper is to determine how much this trend is present in the Republic of Serbia, with a special emphasis on the food industry. Using by regression analysis and based on the results of empirical research, the authors point to factors that determine the size of the supplier base in the food industry in the Republic of Serbia.
\end{abstract}

Key words: upstream, supplier base, supply chain, food industry.

\section{ДИЛЕМА UPSTREAМ ЛАНЦА СНАБДЕВАЊА - ЈЕДАН ИЛИ ВИШЕ ИЗВОРА СНАБДЕВАЊА}

\footnotetext{
Апстракт

Ланци снабдевања, као мреже предузећа, фокусирани су на стварање веће вредности којом би се задовољили захтеви тржишта, а у циљу остваривања веће профитабилности. С тим у вези, сви процеси и активности унутар ланца снабдевања, почев од снабдевања сировина до испоруке готових производа тржишту, морају бити организовани у складу са његовим циљем. Фокус рада је на upstream ланцу снабдевања и на решавању дилеме снабдевања из једног или већег броја извора. Значај овог дела ланца снабдевања произилази из чињенице да сваки евентуални поремећај или прекид у снабдевању може угрозити стварање вредности за потрошаче и опстанак читавог ланца снабдевања. Како је због смањивања комплексности управљања upstream ланцем снабдевања присутан тренд смањивања снабдевачке базе, циљ рада је да утврди колико је овај тренд заступљен у Републици
} 
Србији, на примеру индустрије хране. Применом адекватних статистичких метода и на основу резултата емпиријског истраживања аутори у раду упућују на факторе који опредељују величину снабдевачке базе у индустрији хране у Републици Србији.

Кључне речи: upstream, снабдевачка база, ланац снабдевања, индустрија хране.

\section{INTRODUCTION}

Upstream supply chain includes flows of raw materials (components or parts) from suppliers to manufacturers. The need for supplying from "second hand" is more pronounced, or switch from own sources of supplying to outsourcing supplies. This is due to the fact that many activities are not considered as core activities and should be left to those supply chain partners with those competences. The logic of Henry Ford "you must possess to control it" is gradually outdated (Sweeney, 2013, p. 31). The advantage of outsourcing is transfering of activities that do not add value to a company that are specializes in performing those activities. Therefore, the advantages of supplying raw materials from other sources are obvious. However, the more important question is the decision about optimal number of source of supplying, or size of the supplier base. Managing flows in the upstream supply chain involves monitoring and adapting to current market conditions.

Inadequate upstream supply chain management can jeopardize downstream flows and the delivery of value to consumers (Andjelkovic et al., 2017). Companies spend an average of approximetly $60 \%$ of revenue for raw materials, componets and parts (Monczka et al., 2005). This is one of the reasons for carefully decision making about supplyer base. Adequate supplier base should be use as a source of reducing cost of purchase and competitive advantages (Glock, 2012, p. 318). In this regard, defining an adequate supplier base that will ensure the sustainability and continuity of the process in the supply chain with the establishment of partnership relations has become a very important question. It is not possible to define a supply strategy that will be applicable in each supply chain and industry.

In the paper authors have chosen the most successful companies from food industry, according to the achieved profit, for empirical research. What kind of approach those companies use in the supply process? What is their supplier base? Is it possible to find a common solution among the analyzed companies, which are from the same business sphere? These are the questions that authors will try to answer in the following text.

\section{LITERATURE REVIEW}

Disruptions and disorders in the upstream supply chain could be the result of inadequate supply strategy and/or wrong selection of suppliers that are not capable to provide continuity in supply with available capacities (Anđelković et al., 2017). The logistics strategy is gradually focusing on the fast and direct transport of small lots. Under these conditions it is essential 
that suppliers guarantee that they will deliver the complete order at an agreed time. In order to ensure a fast and reliable response, companies are focused on strategic supply based on careful selection of suppliers which will provide raw materials of the appropriate quality, with lower costs, exchange of innovations, and etc. Decision of developing supply chain has to contain complex analysis of the optimal number of partners. The $4 \mathrm{Rs}$ approach could be use as guidance in the process of defining an optimal supplier base. This approach includes the following elements (Christopher, 2010, p. 8):

- Reliability - represent consistency and predictability of partner behavior over a long period (Handfield, \& Nichols, 2002, p. 166). Reliability depends on the contacts that are set among partners during the time. Also, the degree of reliability is determined by the integrity of the partner, or by operating in accordance with the moral code.

- Responsiveness - it implies a response within the shortest possible period with high level of flexibility. "Working smarter and not harder" is the basis of competitive advantages in contemporary business conditions.

- Relationships - basis of this way of business is the idea that the relationship between customer and supplier must be based on a longterm partnership. Thus, primacy is given to managing by relationships with key suppliers of raw materials, products and services (Sweeney, 2013, p. 31).

- Resilience - Supply chains in modern conditions must be ready to absorb shocks, even if they are confronted with unexpected disruptions. Resilient supply chains possess "amortizers" for overcoming unforeseen situations. For example, the role of "amortizers" could have inventoryes or available capacity. Given that business uncertainty is continually growing, supply chains need to define strategies to mitigate or eliminate identified risks.

The inclusion of a larger or smaller number of suppliers in the supply chain carries with it advantages as well as disadvantages. Decision making about supplying strategy depends on market conditions. According to traditional learning (procurement has an operational role), assumption is that the existence of a sufficient number of suppliers is a priority of the supply chain, while modern learning (supply has strategic importance) emphasizes that competent suppliers are rare resource and that only with those suppliers should be developed long-term relationship. Often, the decision on the number of suppliers is in correlation with relationships established with them. In this sense, decision making about choosing single source of supply often is associated with the establishment of collaborative relationships with suppliers, while decison about muliple suppliers is linked to transactional relations.

Single source of supply, when one supplier is responsible for raw materials procurement, could be an advantage in terms of cost savings and achieving a higher level of quality (Berger et al., 2004, p. 10; Namdar et al., 2018), but this choice brings with it a lower level of resilience. It is certainly desirable that each supply chain have a leader among suppliers, but also it is necessary, whenever it is possible, to provide alternative sources of supply. 
Supply from single source and establishing of collaborative relationships include: using potentials to cost reduction, use of supplier's know-how, faster development of new products, improvement of planning and information exchange with suppliers, early detection of errors, higher quality level (Chen, 2016), simpler supply process, better utilization of resources, reduction of inventory levels, facilitates the implementation of joint innovations, greater mutual trust, and etc. (Larson, \& Kulchitsky, 1998; Gibbs, \& Humphries, 2009, p. 117). Reducing supplier base has become a priority for a lot of companies with developing just-in-time strategy.

Supplier base limited on single source is possible exclusively with development of collaborative relationships (Berger et al., 2004). One of the first things that suffer in the absence of collaborative relationships is quality. Suppliers focused on minimize costs could be threat to performances of the entire supply chain (Christopher, 2011, p. 215). In addition, decide on choice of single source of supply in practice has proved to be very risky. Toyota and it's brake valve crisis from 1997 is example of supply chain disruptions as a result of single supplier base (Yu et al., 2009).

There is a lot of disagreement about this issue. According to some opinions single source of supply is the way for minimizing risks, while other opinions insist on muliple sourcing as a way for overcoming excessive dependence from suppliers, and that is often the main cause of single sourcing. However, although single source of supply has a consequence greater degree of dependence, greater dependence does not mean at the same time a higher risk of supply. In any case, decision abour single or mulitiple source of supply must take into account the possibility of occurrence of dependence between the partners, in particular the asymmetric allocation of dependencies (exist in a situation where purchaser is dependent from supplier or or the opposite). Figure 1 point to the different dependencies between the partners in upstream supply chain, according to importance to purchaser and importance to supplier.

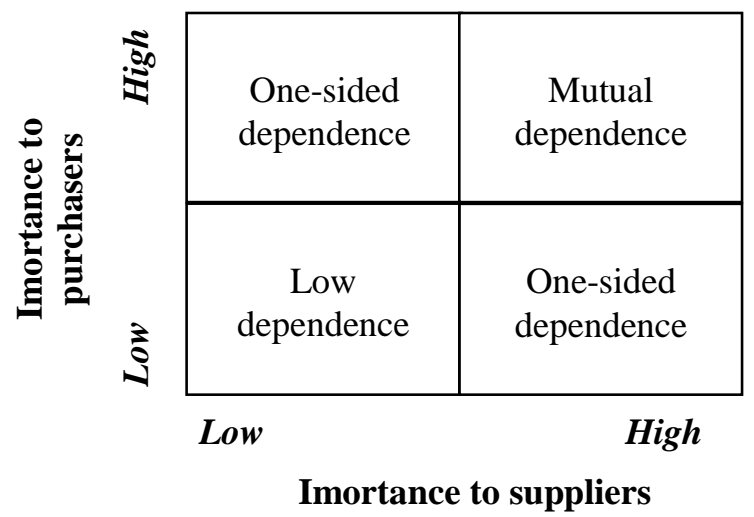

Fig. 1 The dependency matrix

Source: Blome, C. \& Henke, M. (2009). Single versus Multiple Sourcing: A Supply

Risk. In Zsidisin, G. \& Ritchie, B. (Eds.), Supply Chain Risk: A Handbook of Assessment, Management, and Performance (125-136). Springer: New York. p. 131 
If there is a mutual dependency among partners, each parnter will have the same importance to the other in upstream supply chain, and according to that will organize own resources. There are two different cases (Blome, \& Henke, 2009, p. 131):

1. Raw materials and services, as well as relationships with suppliers and the risks that arising from this relationship are marginal, and

2. The level of significance of raw materials, services as well as the relationship with the suppliers and the risks that arising from that relationship is high.

From a risk perspective, mutual dependency can lead to greater supplier flexibility in terms of fulfillment requirements of manufacturer. There will be greater motivation for minimizing costs and increasing quality. But high dependence carries the risk of major consequences in case of interruption. That is the reason why supply chain need to foster a proactive approach to risk management.

For many companies, standard practice was to use miltiple suppliers for most purchased row materials, with the aim suppliers competing against each other. Managers believed that the practice would drive prices down and provide better service. This approach drives the popularity of on-line bidding scenarios, which also known as reverse auctions (Fawcett et al., 2007, p. 319). Significant cost reduction has been achieved through competition online bidding events. Decision making about develop supply chain with a multiple supply is supported by numerous advantages. Participation of larger number of suppliers in supply brings more sources of knowledge and experience that could be used in the process of creating supply chain value. In case that one of the suppliers does not fulfill the obligations on adequate way, it could be easily replaced. Companies want to avoid being dependent of any single supplier. For example, a fire at an Aisin production plant in 1997 (sole-source supplier of brake parts for Toyota), stopped Toyota's production lines and was estimated to cost the company approximately $\$ 40$ million per day (Nelson, et. al., 1998). Mulitple source of supply leads to greater flexibility due to lower costs of replacement of supply sources (Burke et al., 2007, p. 96), no loss of motivation of suppliers due to long-term contracts and the like (Blome, \& Henke, 2009, p. 127). Also, using mulitple source of supply a company can hedge technological risk. Some companies use a multiple-sourcing strategy to learn from different suppliers. For instance, Hewlett-Packard co-founded with Intel the development of the 64bit Itanium processors (formerly called IA-64). Nevertheless, HewlettPackard made the decision to buy AMD's Opteron processor, which could handle both 32-bit and 64-bit applications (Clark, 2005). Finally, companies use multiple suppliers to support global operations.

However, a long and complex supply chain usually has slowly reaction to changes, which implies greater vulnerability and sensitivity to disorders (Tang, \& Tomlin, 2008, p. 12). Participation of larger number of suppliers in the supply chain makes communication between partners more difficult. Also, building a trust relationship is difficult with a great number of suppliers (Berger 
et al., 2004, p. 10). Multiple sourcing represent situation where one supplier plays against another, so poroblem could be potential competition among suppliers (Berger et al., 2004). In supply chain with a mulitple source of supply, it is more difficult to ensure compatibility of goals, strategies, corporate cultures, and etc.

Multiple supply sources could be also cause of disruption in the upstream supply chain. Demand division into a larger number of suppliers leads to reduce the interest of these suppliers for innovation its processes. In case of changes in demand, suppliers will first respond to the demands of their key customers. Multiple supply sources could be the factor of lower level of services and flexiblity than supplying from single source. The conclusion is that less dependence (in case of muliple source of supply) does not necessarily have to be associated with a lower risk of supplying. In any case, the risk of supply may be based on specific situations and it is very difficult to make any generalization.

Muliple source of supply does not lead to an automatic increase of supply chain resilience, especially if strategically important raw materials are in focus. This type of supply could be a reason for increasing vulnerability. Supply from single source is a way for reducing vulnerability in the case of strategic raw materials. Some of the characteristics that are present for single or muliple sources of supply, which can lead to greater resilience of the entire supply chain, are the following (Blome, \& Henke, 2009, p. 132; Burke et al., 2007, p. 96; Yu et al., 2009):

- Single source - the number of potential sources of risk is smaller, risks could be better and easier recognized, and it is easier to manage proactively. However, due to the lack of alternative sources the risk exposure is higher;

- Multiple sources - the problem of managing a large number of supply sources is more pronounced, as well as a likelihood of risk occurrence. Although the likelihood of risk increases, systemic risk management lead to reduce this effect. In this case, the risk of interruptions is lower due to the possibility of supplying from alternative sources.

Therefore, the disadvantages of each supply strategy at the same time are the advantages of the other. In modern conditions, there is a need that one of the key supplier selection criteria be the supplier's risk awareness. For example, do suppliers revise their risk profile? Do they have procedures for monitoring and mitigating risks? It is very important to adopt a proactive strategy for managing relationships with key partners and, in that sense, provide help to suppliers for improving supply chain risk. In the short and medium term, there is often no possibility of making the right decision about supply base. In addition, given the frequent changes in the supply chain environment, does not mean that a defined supply base will always be adequate for a particular supply chain. 


\section{RESEARCH METHODOLOGY}

In following research, the authors focuse on companies from the sphere of processing industry, with a particular emphasis on companies from food industry. Research was conducted at the sample of 17 companies which were selected from the Report of 100 most ... companies in the Republic of Serbia in 2016. These are the companies that recorded significant results in 2016, and on that basis, they were found on the list of the 100 most successful companies in the Republic of Serbia, according achieved net profit.

The choice of the food industry is justified by the fact that companies from this industry belong to the logistics system with the balanced flows of raw materials and products (Barac, \& Milovanović, 2006). This means that the complexity of the management of raw materials is present as much as the complexity of managing the flows of products, in terms of the number of raw materials that enter into production and the number of different products that are the result of production.

For the purpose of the supplier base analysis, i.e. decision making about single or multiple source of supply, it would be possible to select the companies which belong to logistics system with heavy inbound flows. This system implies complexity of the raw materials flows. Because of the importance raw materials flows in these logistics systems, managers are much more committed to these flows, and according to that there is expectation that information collected from them will be more concrete and more realistic. However, having in mind the low level of development of industry with heavy inbound flows (for example automotive, electronic, airline industry), the authors decided to chose food industry for analising the problem of defining size of supplier base. The possibility of including companies from the different industries would not be feasible due to the significant differences between characteristics of markets, raw materials characteristics, way of supplying and deliverying and etc.

In November 2017, survey questionnaires were delivered to procurement, logistics and supply chain managers. In addition to the general information about the company (name, headquarters, ownership form, legal form, etc.), the second part of the questionnaire contain questions about the strategy of supply. Managers were asked about the structure of the suppliers in terms of their size, or whether small and medium enterprises (SME) or large enterprises are dominant in supplier base. In addition, the questionnaire covered the question of the place of supply, or what is the percentage of the companies which are supplied at domestic or some other foreign market. The following table shows the analysis of the sample with regard to the place (or location) of supply, the supplier's structure (according to their size) and supplier base size (the number of suppliers). 
Table 1 Sample analysis

\begin{tabular}{cccccc}
\hline \multicolumn{2}{c}{ Origin of capital } & \multicolumn{2}{c}{ Size of suppliers } & \multicolumn{2}{c}{ Place of supply } \\
\hline Domestic & Foreign & $\begin{array}{c}\text { Large } \\
\text { enterprises }\end{array}$ & SME & Domestic & Foreign \\
\hline $29 \%$ & $71 \%$ & $53 \%$ & $47 \%$ & $65 \%$ & $35 \%$ \\
\hline
\end{tabular}

Source: Autors' calculation

Since the sample includes producers of confectionery products, where it is not possible to purchase all the raw materials from the one supplier and for example producers of meat products where that might be the case, in the following analysis authors will identify all companies that procure their key raw material from one source as single source. Accorditng to table 1, it can be noticed that supplier base is composed by large enterprises, in larger percentage. Also, due to the characteristics of raw materials and finished products, it is not a surprise that the structure of the suppliers is dominated those from the territory of the Republic of Serbia. All the companies from the sample belong to group of large enterprises, with differences in the origin of capital. In the sample, only $29 \%$ of companies have predominant share of domestic capital.

In order to determine possible rules in process of decision making about size of the supplier base in the food industry in the Republic of Serbia, the authors examine the influence of certain factors: ratio of participation of large and medium-sized enterprises in the supplier base, as well as the place of supply. Thus, the following hypothesis are defined and tested in following chapter:

H1: The size of the supplier base is determined by origin of capital.

$\mathrm{H} 2$ : The size of the supplier base is conditioned by the ratio of the participation of large and medium-sized suppliers.

H3: The size of the supplier base is determined by the place of supply.

\section{RESEARCH RESULTS AND DISCUSSION}

For the purposes of testing hypotheses, the authors use a regression analysis, method of determining one or several independent variables' impact on a dependent variable In that sense the size of the supplier base is formulated as dependent variable, while the origin of capital, place (or location) of supply and size of suppliers are formulated as independent variables. Using by simple linear regression analysis in SPSS Statistics for the purpose of analyzing the ratio of the size of supplier base and origin of capital it is confirmed that the size of supplier base depends on the origin of capital. Unstandardised coefficient, in Table 2, shows that Supplier base as dependent variable will be change for 0.633 if Origin of capital will change, as independent variable, by one unit, keeping other independent variables constant. Standardized coefficient and Beta value of 0.604 indicates that a change of one standard deviation in the Origin of capital (independent variable) results in a 0.604 standard deviations increase in the Supplier base 
(dependent variable). Table 2 shows that significance is lower than 0.05 (Sig. $=0.010)$.

Table 2 Regression analysis (Origin of capital vs Supplier base)

\begin{tabular}{lrrrrrr}
\hline & \multicolumn{2}{c}{$\begin{array}{l}\text { Unstandardized } \\
\text { Coefficients }\end{array}$} & \multicolumn{2}{c}{$\begin{array}{c}\text { Standardized } \\
\text { Coefficients }\end{array}$} & t & \multirow{2}{*}{ Sig. } \\
\cline { 2 - 6 } & B & \multicolumn{2}{c}{ Std. Error } & Beta & & \\
\hline Origin of capital & .633 & & .216 & .604 & 2.934 & .010 \\
\hline
\end{tabular}

a. Dependent Variable: Supplier base

$$
\text { Source: Authors' calculation }
$$

This result could be explained by the emergence of a trend in global supply chains in terms of reducing the supply base (Faisal, 2009, p. 44; Behdani et al., 2012). The presence of foreign capital on the domestic market could lead to the transfer of trends from the global market. Given the fact that more than $70 \%$ of companies in the tested sample are with majority foreign capital, their influence on adopting this global trend on the domestic market is possible, despite the fact it turned out that this trend is very risky (Ivanov, 2017, p. 24). Reduced supply base does not provide amortizers in case of disruptions and breaks; and in case of occurrence of risk events, companies have very little available resources and alternatives for reacting (Anđelković, 2015, p. 52). Some of the examples are: Ericsson and Philips in 2000, when the fire in Philips' production caused the stop production of Ericsson and 400 million euros of damage; In 1998, because of problems with locking mechanisms for doors and luggage Ford had a 3-day suspension of production and damage of 100 million euros; Toyota suffered damage worth $\$ 300$ million in 1997 due to a fire at the Aisin plant, which is associated with the Toyota Just-in-Time system (Blome, \& Henke, 2009, p. 130).

Table 3 shows the results of testing the first hypothesis. The results of the regression analysis show that Sig. $<0.05($ Sig. $=0.026)$, and that confirms the first hypothesis. This result shows that the companies from the sample define its supplier base accorting to size of their partners. As size of the partner ussually points to the available capacities and their ability to respond to the requirements of the manufacturer at determined place and time, it is justified that companies from the sample use size of suppliers as a factor of size of the supply base. Therefore, by confirming the first hypothesis, the impression is that companies from the sample have a proactive approach to risk managment, caused by delaying due to unavailable capacity or longer lead time.

Table 3 Regression analysis (Size of supplier vs Supplier base)

\begin{tabular}{lccccc}
\hline & \multicolumn{2}{c}{$\begin{array}{c}\text { Unstandardized } \\
\text { Coefficients }\end{array}$} & $\begin{array}{c}\text { Standardized } \\
\text { Coefficients }\end{array}$ & t & \multirow{2}{*}{ Sig. } \\
\cline { 2 - 6 } & $\mathrm{B}$ & Std. Error & Beta & & \\
\hline Size of suppliers & .514 & .209 & .537 & 2.464 & .026 \\
\hline
\end{tabular}

a. Dependent Variable: Supplier base

Source: Authors' calculation 
In order to test the second hypothesis, the same principles and method have been used. The results of testing the relationship between the place of supply and the size of supplier base are shown in Table 4. According to these results, it can be concluded that the size of supplier base is not determined by the place of supply $($ Sig. $=0.808)$.

Table 4 Regression analysis (Place of supply vs Supplier base)

\begin{tabular}{ccccccc}
\hline & \multicolumn{2}{c}{$\begin{array}{c}\text { Unstandardized } \\
\text { Coefficients }\end{array}$} & \multicolumn{2}{c}{$\begin{array}{c}\text { Standardized } \\
\text { Coefficients }\end{array}$} & t & \multirow{2}{*}{ Sig. } \\
\cline { 2 - 6 } & B & Std. Error & Beta & & \\
\hline Place of supply & .067 & .270 & .064 & .247 & .808 \\
\hline a. Dependent Variable: Supplier base \\
Source: Authors' calculation & & &
\end{tabular}

The second hypothesis is formulated under the assumption that in the case companies supplying in a higher percentage outside the domestic market, will be provide a multilple sources of supply in order to overcome potential problems that would be result of delays. Delivery delays are more evident in supplying from foreign markets because of higher physical distances, customs and customs regulations and procedures, and etc. However, according to the results of regression analysis, this factor of supply is not crucial in defining the size of supplier base. More detailed analysis of the place of supply of the companies from the sample confirmed that companies which found suppliers in a higher percentage outside the Republic of Serbia in $65 \%$ of cases are supplying from the territory of Eastern Europe. Since these are countries that are in the immediate environment of the Republic of Serbia this may be one of the reasons why companies from the sample do not recognize this factor as an important element in defining the size of supplier base.

\section{CONSLUSION}

Today's supply chains are more vulnerable because of high level of interdependence among the supply chain partners. So for purpose of increasing resilience supply chains need to be proactive in process of developing adequate supplier base. Beside a many studies about advantages and disadvantages of single or multiple source of supply, still do not exist universal approach for decision making about the size of supplier base (Berger, \& Zeng, 2006, p. 259). Also, in the short and medium term, often it is not possibile to make the right decision about size of supplier base.

One of the key limitation for defining the framework for decision making about the size of supplier base is frequent changes in the supply chain environment, both internal and external. Under the influence of such changes defined supplier base will not always be adequate for supply chains, even if they are from the same industry (Anđelković, 2015, p. 123). Previous research shows that companies from sample as a factors for defining size of supplier base use origin of capital and size of suppliers. But, with the change of an 
internal or external environment, other research over the same sample can show completely different results. Of course the choice between the single and multiple sources of supplying is not possible in situations when producers does not have posibilities for choosing and have only one solution, known as sole supplier.

In that sense, it is possible to define only certain guidelines that need to be followed in order to build a sustainable and resilient supplier base (Pochard, 2003, p. 48):

- Compexity vs. Resilience - Building resilient supplier base offers many advantages to partners. However, the need to adapt to the frequent changes requires a high level of flexibility of supplier base. A flexible supplier base with muliple sources implies greater complexity, which negatively affects on resilience. As a result, tradeoff between the level of complexity and resilience is suggested.

- Trade-off risks - Also, the presence of the trend of supplier base reduction can not be ignored. In this way, producers want to achieve all the benefits that would be achieved by multiple source of supplying but with establishing of long-term partnerships with suppliers (Zeng, 1998). On the one hand, this action has many advantages, what has already been discussed in the paper. However, reduced of supplier bese also exposes the members of the whole supply chain on greater risk, and in this case a trade-off should be reached.

- Cost efficiency vs. Resilience - In defining an adequate supply base, should be considered the trade-off between the inventory costs (which are higher at single source of suppling due to higher resilience in case of occurrence of unforeseen events) and the resilience or the ability to respond to unforeseen events through multiple source of suppling, without high level of inventory. It is necessary to analyze whether the reduction in inventory costs will increase the risk of business, and whether greater flexibility, achieved by increasing the level of inventories, will justify a higher level of costs.

Showed research is a kind of pilot research, which should raise new issues and interest about defining adequate supplier base. In further researches, it is possible to analyze some new factors that may have an impact on defining supplier base. What has not been the subject of the analysis and which can certainly have a significant impact on determining size of supplier base are the criteria for selecting suppliers, quantity and frequency of ordering (Constantino, \& Pellegrino, 2010). Also, the question is whether the downstream supply chain and the partners from this part of supply chain an impact on could have defining adequate supplier base. 


\section{REFERENCES}

Агенција за привредне регистре (2016). 100 нај привредних друштава у Републици Србији у 2016. - Подаци из редовних годишњих финансијских извештаја [100 the best... companies in the Republic of Serbia in 2016. - Data from the regular annual financial reports]. Retrieved from http://www.apr.gov.rs/Portals/ 0/GFI\%202016/TOP\%20100-2016\%2019102017.pdf?ver=2017-10-19-122110997

Anđelković, A. (2015). Supply chain risk managment for the purpose of increasing its resilience (Ph.D. Thesis).

Anđelković, A., Barac, N. \& Radosavljević, M. (2017). Analysis of Factors of Disruptions/Interruptions in Upstream Supply Chain and Their Influence on Vulnerability. Themes - Journal for Social Science, 41(2), 489-502. DOI: 10.22190/TEME1702489A

Barac, N., Milovanović, G. (2006). Strategijski menadžment logistike. Niš: SKC.

Behdani, B., Adhitya, A., Lukszo, Z. \& Srinivasan, R. (2012). How to Handle Disruptions in Supply Chains - An Integrated Framework and a Review of Literature. Retrieved from http://papers.ssrn.com/sol3/papers.cfm?abstract_id=2114201

Berger, P.D. \& Zeng, A.Z. (2006). Single versus multiple sourcing in the presence of risks. Journal of the Operational Research Society, 57(3): 250-261.

Berger, P.D., Gerstenfeld, A. \& Zeng, A.Z. (2004). How many suppliers are best? A decision-analysis approach. Omega, 32(1): 9-15.

Blome, C. \& Henke, M. (2009). Single versus Multiple Sourcing: A Supply Risk. In Zsidisin, G., \& Ritchie, B. (Eds.), Supply Chain Risk: A Handbook of Assessment, Management, and Performance (pp. 125-136). New York: Springer.

Burke, G.J., Garrillo, J.E. \& Vakharia, A.J. (2007). Single versus multiple supplier sourcing strategies. European Journal of Operational Research, 182(1): 95-112.

Chen, J. (2016). Sourcing for Quality: Cooperating with a Single Supplier or Developing Two Competing Suppliers? Mathematical Problems in Engineering, 4: 1-13.

Christopher, M. (2010). New Directions in Logistics. In Waters, D. (Ed.), Global Logistics: New Directions in Supply Chain Management (pp. 1-13). London: Kogan Page.

Christopher, M. (2011). Logistics \& Supply Chain Management. London: Prentice Hall.

Clark, D. (2005). Intel's next CEO charts new course. The Wall Street Journal, January $12, \mathrm{~B} 1$.

Constantino, N. \& Pellegrino, R. (2010). Choosing between single and mulitple sourcing based on supplier default risk: A real options approach. Journal of Purchasing \& Supply Managment, 16(1): 27-40.

Faisal, N. (2009). Prioritization of Risks in Supply Chains. In Wu, T. \& Blackhurst, J. (Eds.), Managing Supply Chain Risk and Vulnerability: Tools and Methods for Supply Chain Decision Makers (pp. 9-28). London: Springer.

Fawcett, S.E., Ellram, L.M. \& Ogden, J.A. (2007). Supply Chain Management-From Vision to Implementation. New Jersy: Pearson Education, Inc.

Gibbs, R. \& Humphries, A. (2009). Strategic Alliances and Marketing Partnership: Gaining Competitive Advantage through Collaboration and Partnering. London and Philadelphia: Kogan Page.

Glock, Ch.H. (2012). Single sourcing versus dual sourcing under conditions of learning. Computers \& Industrial Engineering, 62(1): 318-328.

Handfield, R.B. \& Nichols, E.L. (2002). Supply Chain Redesign: Transforming Supply Chains into Integrated Value System. New York: Prentice Hall. 
Ivanov, D. (2017). Simulation-Based Single vs. Dual Sourcing Analysis in the Supply Chain with Consideration of Capacity Disruptions, Big Data And Demand Patterns. International Journal of Integrated Supply Management, 11(1): 24-43.

Larson, P.D. \& Kulchisky, J.D. (1998). Single sourcing and supplier certification: performance and relationship implications. Industrial Marketing Management, 27(1): 73-81.

Monczka, R.M., Trent, R.J. \& Handfield, R.B. (2005). Purchasing and Supply Chain Management. London: South-Western College Publication.

Namdar, J., Li, X., Sawhney, R. \& Pradhan, N. (2018). Supply Chain Resilience for Single and Multiple Sourcing in the Presence of Disruption Risks. International Journal of Production Research, 56(6): 2339-2360.

Nelson, D., Mayo, R. \& Moody, P.E. (1998). Powered by Honda: Developing Excellence in the Global Enterprise. New York: John Wiley \& Sons.

Pochard, S. (2003). Managing Risks of Supply-Chain Disruptions: Dual Sourcing as a Real Option (Master's thesis). Retrieved from http://ardent.mit.edu/real_ options/Real_opts_papers/Master_Thesis-Sophie.pdf

Sweeney, E. (2013). Supply Chain "Mega-Trends": Current Status and Future Trends. Journal of the Chartered Institute of Logistics and Transport (CILT) in Ireland, 4: 31-34.

Tang, Ch. \& Tomlin, B. (2008). The Power of Flexibility for Mitigating Supply Chain Risks. International Journal of Production Economics, 116(1): 12-27.

Yu, H., Zeng, A.Z. \& Zhao, L. (2009). Single or dual sourcing: decision-making in the presence of supply chain disruption risks. Omega, 37(4): 788-800.

Zeng, Z.A. (1998). Single or mulitple sourcing: An integrated optimization framework for sustaining time-based competetiveness. Journal of Marketing Theory and Practice, 6(4): 10-25.

\section{ДИЛЕМА UPSTREAМЛАНЦА СНАБДЕВАНА - ЈЕДАН ИЛИ ВИШЕ ИЗВОРА СНАБДЕВАЊА}

Александра Анђелковић, Горан Миловановић

Универзитет у Нишу, Економски факултет, Ниш, Србија

\section{Резиме}

Одрживост и развој сваког ланца снабдевања условљени су његовим дизајном и адекватним начином организовања партнера који га чине. У различитим индустријама upstream и downstream ланца снабдевања неће бити подједнако значајни. На пример у индустријама са израженијим токовима материјала (какве су аутомобилска, електронска и авио индустрија) upstream ланца снабдевања ће бити много сложенији, па ће и захтеви у погледу организовања овог дела ланца бити много већи. Како је у свету у пракси све присутније смањивање снабдевачке базе и фокус компанија на сарадњу са мањим бројем добављача намеће се потреба анализе писутности овог тренда на продручју Републике Србије. Смањивање снабдевачке базе за компаније значи у исто време и изградњу дугорочних односа и односа поверења са добављачима, што се често наводи као кључна предност оваквог начина организовања upstream ланца снабдевања. 
Аутори се у раду величину снабдевачке базе анализирају над групом предузећа из прехрамбене индустрије, а која су се претходних година према Агенцији за привредне регистре нашла на листи најуспешнијих. Одлука о избору прехрамбене индустрије оправдава се чињеницом да је upstream код предузећа која припадају овој индустрији јако развијен, с обзиром на број и разноврсност сировина. Аутори у раду прате утицај појединих фактора на величину снабдевачке базе. Реч је о пореклу капитала, величини добављача и извору, односно пореклу снабдевања. Регресионом анализом утвређено је да прва два фактора имају утицај на величину снабдевачке базе, док порекло снабдевања нема такав утицај.

У сваком случају поред фактора који су анализирани у раду могу се издвојити и неки други фактори који би били специфични за конкретна предузећа, односно њихово оркужење. Зато је немогуће направити универзални оквир за појединачне индустрије и предузећа која њима припадају. Дефинисање снабдевачке базе јесте одлука која има стратегијски карактер, мећутим свакако није одлука која се неће мењати током развоја предузећа, а у складу са његовим оркужењем и променама које се дешавају. 